\title{
A regulatory RNA is associated to invasive meningococcal disease in Europe
}

\author{
Jens Karlsson a . Hannes Eichner ${ }^{\text {a }}$, Susanne Jacobsson ${ }^{\text {b }}$, Edmund Loh ${ }^{\text {a,c,1 }}$ \\ ${ }^{a}$ Department of Microbiology, Tumor- and Cell biology, BioClinicum, Karolinska University Hospital, Stockholm, Sweden \\ ${ }^{\mathrm{b}}$ National Reference Laboratory for Neisseria meningitidis, Department of Laboratory Medicine, Faculty of Medicine and \\ Health, Örebro University, Örebro, Sweden \\ ${ }^{\mathrm{c}}$ SCELSE, Nanyang Technological University, Singapore \\ ${ }^{1}$ Correspondence: edmund.loh@ki.se
}

\begin{abstract}
The strictly human pathogen Neisseria meningitidis is a commensal bacterium but can occasionally turn lethal causing septicaemia and meningitis. The mechanisms of how the meningococcus shifts to invasive infection remain poorly understood. Here we demonstrate that an eight base-pair tandem repeat deletion in the 5 '-untranslated region of the polysaccharide capsular biosynthesis operon results in a hypercapsulation phenotype in clinical isolates. The increased capsule production significantly improves the bacterium survival in human serum while impairing its ability to adhere and colonise human pharyngeal cells. Among 4501 reported meningococcal cases in Europe from 2010-2018, the loss of an eight base-pair tandem repeat is three times more prevalent in invasive isolates $(16.3 \%)$ compared to carrier isolates $(5.1 \%)$.Combined results indicate that polymorphisms in this regulatory RNA contributes to meningococcal virulence.

Importance In this study we report a regulatory RNA to be directly involved in clinical manifestation of meningococcal disease. Using readily accessible WGS of meningococcus, we have now demonstrated that regulatory RNAs directly contribute to the progression of invasive meningococcal infection. We believe this novel combination of molecular and comparative regulatory RNA study could be used for the identification of additional RNAs involved in not only meningococcus but also pave the way for similar studies in other important bacterial pathogens. The identification of specific regulatory RNAs will no doubt facilitate clinicians, microbiologists, and public health practitioners to adjust their diagnostic techniques and treatments to best fit the condition of the patients.
\end{abstract}

Keywords: sRNA, tandem repeats, polysaccharide capsule, Neisseria meningitidis, meningococcal disease

\section{Introduction}

Neisseria meningitidis is a Gram-negative diplococcus and an obligate human commensal bacterium, which resides exclusively on the epithelium of the nasopharynx. Carriage is age-dependent and rises from $4.5 \%$ in infants ( $0-1$ years) to $23.7 \%$ in adolescents $(15-19$ years) and down to $7.8 \%$ in middle aged adults (50 years) (1). By mechanisms not fully understood, the harmless colonisation can rapidly turn into an invasive infection leading to lethal septicaemia and meningitis. The incidence of invasive meningococcal disease is highly dependent on geographical region and season, and ranges from $0.1 / 100,000 /$ population/year to almost 100/100,000/population/year (2). People with increased risk for invasive meningococcal infections are infants, adolescents and immunocompromised individuals (ㅍ-5).

Currently, there are twelve known serogroups of $N$. meningitidis identified based on the composition of their capsular polysaccharide (A, $\mathrm{B}, \mathrm{C}, \mathrm{E}-\mathrm{H}, \mathrm{I}-\mathrm{K}, \mathrm{L}-\mathrm{W}, \mathrm{X}, \mathrm{Y}, \mathrm{Z}$ ) with six of these responsible for outbreaks; A, B, C, W, X, and Y (6). The capsular synthesis (cps) locus has been characterised for a wide range of serogroups and shows gene order synteny (ㅁ). In addition to serogroup, meningococci can be grouped into clonal complexes (cc) and sequence types (ST) by multilocus sequence typing (MLST) based on polymorphisms in housekeeping genes (7). In this study, we investigated meningococcal isolates from two Swedish adolescents who contracted meningococci after attending a ski trip to the French Alps in March 2017. During the trip one adolescent contracted invasive meningococceamia and recovered. Two months later after returning home to Sweden, another adolescent succumbed to invasive meningococceamia and a third adolescent was identified as an asymptomatic carrier. This study aims to elucidate and compare virulence mechanisms underlying the cause for the fatal meningococcal infection especially in the regulation of its polysaccharide capsule production. Using findings from the Swedish isolates, the subsequent work encompasses the investigation of correlations in the manifestation of diseases between 4501 meningococcal invasive- and carrier isolates from Europe.

\section{$\underline{\text { Results }}$}

We whole-genome sequenced (WGS) both the Swedish meningococcal isolates used in this study and deposited them in the PubMLST database under following IDs; 17-264: 53777 (invasive isolate) and 17-271: 53778 (carrier isolate). Both isolates were identified to belong to serogroup C, cc32 and with identical typing genes as the French isolate (Table 1). Bacterial growth, micro-, and macroscopical examinations revealed no significant difference between the isolates (Fig S1 and S2). Loci similarity comparison from the WGS encompassing 2219 loci revealed $98.3 \%$ (2181) loci conservation (Table EV2). The $1.7 \%$ (38) different loci between the isolates comprise of incomplete IS1655 transposase insertions in the 17-271 isolate, together with genes coding for outer membrane proteins, efflux pumps, and metabolic proteins (Table 3). Further analyses revealed that many hits of the variable loci where due to single nucleotide polymorphisms (SNPs) that were either true SNPs or sequencing errors. All true SNPs identified were found to generate the same gene products in both isolates. In addition, other hits were also later identified as sequencing error due to long Poly-G or Poly-C regions present over the locus. 
bioRxiv preprint doi: https://doi.org/10.1101/583476; this version posted March 20, 2019. The copyright holder for this preprint (which was not certified by peer review) is the author/funder, who has granted bioRxiv a license to display the preprint in perpetuity. It is made available under aCC-BY 4.0 International license.

Karlsson et al., 20-03-2019 - preprint copy - BioRxiv

Table 1. Typing output of 17-264 and 17-271 isolates recovered from PubMLST as well as the typing of the isolate responsible for the infection in the French Alps.

\begin{tabular}{|c|c|c|c|c|c|c|c|c|c|c|c|}
\hline \multicolumn{7}{|c|}{ Isolate fields } & \multicolumn{2}{|c|}{ MLST } & \multicolumn{3}{|c|}{ Finetyping antigens } \\
\hline ID & Isolate & Country & Year & Disease & Species & $\begin{array}{c}\text { Capsule } \\
\text { group }\end{array}$ & ST & $\begin{array}{c}\text { Clonal } \\
\text { complex }\end{array}$ & $\begin{array}{l}\text { PorA } \\
\text { VR1 }\end{array}$ & $\begin{array}{l}\text { PorA } \\
\text { VR2 }\end{array}$ & $\begin{array}{c}\text { FetA } \\
\text { VR }\end{array}$ \\
\hline $\begin{array}{c}\text { Not } \\
\text { available }\end{array}$ & $\begin{array}{c}\text { Not } \\
\text { available }\end{array}$ & France & 2017 & Invasive & $\begin{array}{c}\text { Neisseria } \\
\text { meningitidis }\end{array}$ & $\mathrm{C}$ & 32 & $\begin{array}{c}\text { ST-32 } \\
\text { complex }\end{array}$ & 7 & $16-29$ & F3-3 \\
\hline$\underline{\mathbf{5 3 7 7 7}}$ & $17-264$ & Sweden & 2017 & Invasive & $\begin{array}{c}\text { Neisseria } \\
\text { meningitidis }\end{array}$ & $\mathrm{C}$ & 32 & $\begin{array}{c}\text { ST-32 } \\
\text { complex }\end{array}$ & 7 & $16-29$ & F3-3 \\
\hline$\underline{\mathbf{5 3 7 7 8}}$ & $17-271$ & Sweden & 2017 & Carrier & $\begin{array}{c}\text { Neisseria } \\
\text { meningitidis }\end{array}$ & $\mathrm{C}$ & 32 & $\begin{array}{c}\text { ST-32 } \\
\text { complex }\end{array}$ & 7 & $16-29$ & F3-3 \\
\hline
\end{tabular}

The final five hits confirmed as different are NEIS0210 (pilE),

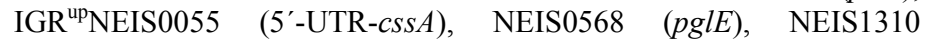
(modA12), and NEIS2986 (hypothetical protein) (Highlighted in Table EV3). The pilE gene encodes for the major subunit of Type-IV pilus (T4P) and is different due to antigenic variation, usually observed even within the same clonal population ( 8 ). The 5 '-untranslated region (UTR) of the capsular biosynthesis operon $\operatorname{css} A$ of the invasive isolate 17-264 lacks an eight base pair (8bp) tandem repeat (5'-TATACTTA$\left.3^{\prime}\right)$. The $p g l E$ gene is involved in the glycosylation of T4P and is known for its ON/OFF phase-variation depending on heptarepeats $\left(5^{\prime}-\right.$ CAAACAA-3') (9). The two isolates have different transcriptional pglE frames due to different amount of heptarepeats but both result in the same OFF phase. Similar to the regulation to $\mathrm{pglE}$, the $\operatorname{modA12}$ gene encoding a methyltransferase of DNA is regulated by tetrarepeats, $5^{\prime}$ AGCC-3' (10) and although both isolates have different amounts of repeats, they are both in the same OFF phase. NEIS2986 is a hypothetical protein of 90 amino acid, with no elucidated function and no recognised protein motifs. The predicted protein sequence does not contain start codon, which indicate that this is a pseudogene. Overall, among the 38 loci identified as different, the only bona fide hit is the 5'UTR- $\operatorname{css} A$ between the two isolates.

Through immunoblot analysis, we reveal that the invasive isolate 17264 has a higher expression of CssA (capsular synthesis protein), PilE (predominant minor pilin in the T4P involved in adhesion), and Opa,(opacity proteins involved in adhesion) (Fig 1A). Expression of other virulence factors such as fHbp, (responsible for sequestering immune factor H), Hfq (RNA-chaperone important for sRNA-mediated gene regulation), PorA (voltage-gated, cation channel) RmpM (periplasmic protein interacting and stabilising PorA and PorB), and other pilin proteins (pilus and pilus-associated proteins that form the T4P) remain same for both isolates and were used as controls.

The capsular polysaccharide $\operatorname{css} A$ coding region was also initially annotated as different between the isolates (Table EV3), but further examination reveals the presence of a single base polymorphism but coding for the same amino acid and therefore does not explain the higher expression of CssA in invasive isolate 17-264 compared to carrier isolate 17-271. These observations prompted us to further investigate into the regulatory region of the capsular polysaccharide operon.

The WGS data reveal the loss of an $8 \mathrm{bp}$ tandem repeat in the $5^{\prime}$-UTRcss $A$ region of the invasive isolate 17-264 compared to the carrier isolate 17-271 (Fig 1B). Secondary structure predictions of the $5^{\prime}$-UTRcssA mRNA confirms a possible stem-loop formation in the carrier isolate $17-271(\Delta G:-15 \cdot 60 \mathrm{kcal} / \mathrm{mol})$, while the invasive isolate $17-264$ possess a thermodynamically less stable $(\Delta G:-11.30 \mathrm{kcal} / \mathrm{mol})$ secondary structure (Fig 1C). Previously, we identified that the 5 '-UTR$\operatorname{css} A$, functions as an RNA-.thermosensor, controlling the expression of CssA in a temperature dependent manner (11). We therefore investigated temperature dependent expression of CssA in these two clinical isolates. Results show a temperature-mediated upregulation of CssA in the 17-264 whereas the level of CssA in the 17-271 remained low (Fig 1D - top). Since a bona fide RNA-thermosensor should be able to function independently of the native bacterial host factors, an ectopic bacterial host (Escherichia coli) was selected to further investigate this thermal regulation. The respective 5'-UTR-css $A$ from each isolate was introduced upstream of a green fluorescent reporter EGFP in the pEGFP-N2 vector and transformed into E. coli. Immunoblot results from $E$. coli were consistent with their respective meningococcal background (Fig 1D - lower).

Table 2. Summary of loci comparison between 17-264 and 17-271 isolates. Missing-, and incomplete loci in both isolates were excluded from calculations

\begin{tabular}{|c|c|c|c|c|}
\hline Matching loci & Missing loci & Different loci & Incomplete loci & Frequency matching (\%) \\
\hline 2181 & 763 & 38 & 60 & 98,3 \\
\hline
\end{tabular}


bioRxiv preprint doi: https://doi.org/10.1101/583476; this version posted March 20, 2019. The copyright holder for this preprint (which was not certified by peer review) is the author/funder, who has granted bioRxiv a license to display the preprint in perpetuity. It is made available under aCC-BY 4.0 International license.

Karlsson et al., 20-03-2019 - preprint copy - BioRxiv

Table 3. List of the 38 different loci in the WGS comparison between 17-264 and 17-271.

\begin{tabular}{|c|c|c|}
\hline Locus & Product & Cause/Effect \\
\hline NEIS0210 & pilE & Antigenic variation \\
\hline NEIS0568 & pglE & $\begin{array}{c}\text { 7bp tandem repeats (17-264: } 11 \text { and 17-271: 13), different frame } \\
\text { but both off phase }\end{array}$ \\
\hline NEIS2986 & hypothetical protein & Different, pseudogene \\
\hline igr_up_NEIS0055 & 5'-UTR-css $A$ & $\begin{array}{c}\text { 8bp tandem repeat missing } \\
\text { in } 17-264\end{array}$ \\
\hline NEIS1310 & $\operatorname{modA12}$ & $\begin{array}{c}\text { 4bp tandem repeats (17-264: } 14 \text { and 17-271: } 23) \text {, same frame } \\
\text { and both off phase }\end{array}$ \\
\hline NEIS0033 & pilC2 & $\begin{array}{l}\text { Poly-G region sequencing error. } \\
\text { WB shows no difference }\end{array}$ \\
\hline NEIS0054 & $\operatorname{css} A$ & SNP \\
\hline NEIS0085 & protein export protein & End of contig* in 17-271 sequencing but otherwise identical \\
\hline NEIS0213 & pglA & $\begin{array}{c}\mathrm{SNP} / \text { undecided nucleotide } \\
\text { in sequencing }\end{array}$ \\
\hline NEIS0297 & insertion element $I S 1655$ transposase & Incomplete transposase element in $17-271$ \\
\hline NEIS0377 & putative integral membrane protein & $\begin{array}{c}\mathrm{SNP} / \text { undecided nucleotide } \\
\text { in sequencing }\end{array}$ \\
\hline NEIS0380 & $\operatorname{pglL}$ & End of contig* in 17-264 sequencing but otherwise identical \\
\hline NEIS0402 & $p g l F$ & End of contig* in 17-264 sequencing but otherwise identical \\
\hline NEIS0493 & hypothetical protein & $\begin{array}{l}\text { 5' sequencing error, } \\
\text { undecided nucleotides }\end{array}$ \\
\hline NEIS0648 & $k s g A$ & $\begin{array}{l}\mathrm{SNP} / \text { undecided nucleotide } \\
\text { in sequencing }\end{array}$ \\
\hline NEIS0710 & pnp & SNP \\
\hline NEIS0715 & cysteine synthase & SNP \\
\hline NEIS0904 & transposase for $I S 1655$ & $\begin{array}{l}\text { Incomplete transposase element } \\
\text { in } 17-271\end{array}$ \\
\hline NEIS0976 & transposase for $I S 1655$ & $\begin{array}{l}\text { Incomplete transposase element } \\
\text { in } 17-271\end{array}$ \\
\hline NEIS1008 & transposase for $I S 1655$ & $\begin{array}{l}\text { Incomplete transposase element } \\
\text { in } 17-271\end{array}$ \\
\hline NEIS1055 & transposase for $I S 1655$ & $\begin{array}{l}\text { Incomplete transposase element } \\
\text { in } 17-271\end{array}$ \\
\hline NEIS1085 & $m p l$ & SNP \\
\hline NEIS1156 & hypothetical protein & SNP, Poly-G region sequencing error \\
\hline NEIS1288 & putative aldehyde dehydrogenase & SNP and end of contig* \\
\hline NEIS1381 & transposase for $I S 1655$ & $\begin{array}{l}\text { Incomplete transposase element } \\
\text { in } 17-271\end{array}$ \\
\hline NEIS1418 & putative membrane peptidase & Sequencing error \\
\hline NEIS1852 & farA & Sequencing error and end of contig* \\
\hline NEIS1853 & $\operatorname{far} B$ & End of contig* \\
\hline NEIS1884 & transposase for $I S 1655$ & $\begin{array}{l}\text { Incomplete transposase element } \\
\text { in } 17-271\end{array}$ \\
\hline NEIS1902 & $\operatorname{lgt} A$ & Poly-G region sequencing error and end of contig* \\
\hline NEIS1926 & putative inner membrane protein & End of contig* \\
\hline NEIS1943 & nalP & SNP, Poly-C region sequencing error in $17-271$ \\
\hline NEIS1993 & insertion element $I S 1655$ transposase & $\begin{array}{c}\text { Incomplete transposase element } \\
\text { in } 17-271\end{array}$ \\
\hline NEIS2099 & putative immunity protein & Sequencing error and end of contig* \\
\hline NEIS2124 & lipoprotein & End of contig* \\
\hline NEIS2125 & insertion element $I S 1655$ transposase & $\begin{array}{l}\text { Incomplete transposase element } \\
\text { in } 17-271\end{array}$ \\
\hline NEIS2155 & $\operatorname{lgt} D$ & Poly-G region sequencing error and end of contig* \\
\hline igr_up_NEIS1364 & porA promoter & $\begin{array}{c}\text { SNP in 17-271. } \\
\text { WB shows no difference } \\
\end{array}$ \\
\hline
\end{tabular}

*End of contig refers to sequencing contig is incomplete in covering the loci in one WGS sample and therefore are in the list as different. Unless stated 3 otherwise the sequencing is identical up to that point 
bioRxiv preprint doi: https://doi.org/10.1101/583476; this version posted March 20, 2019. The copyright holder for this preprint (which was not certified by peer review) is the author/funder, who has granted bioRxiv a license to display the preprint in perpetuity. It is made available under aCC-BY 4.0 International license.

Karlsson et al., 20-03-2019 - preprint copy - BioRxiv

An elevated expression of the CssA protein is however not definite evidence that more surface capsule is produced. To address this, "dot blots" assays were performed, as it has previously been used to semiquantitatively measure meningococcal capsule production (12-14). Dot blots using serogroup $\mathrm{C}$ specific anti-sera show that surface polysaccharide capsule is produced in high amounts regardless of cells, Detroit 562 were performed. Results reveal that the less capsulated carrier 17-271 isolate has a significant, ten times more effective adherence to the cells compared to the hypercapsulated invasive 17-264 isolate (Fig 2B).

These findings from the Swedish isolates prompted the question on
A

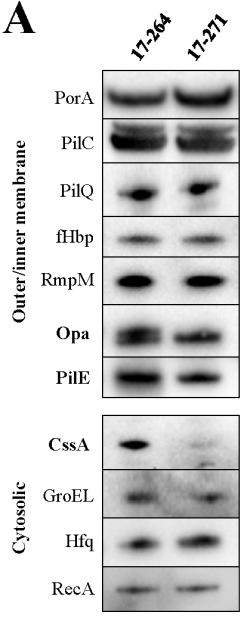

B

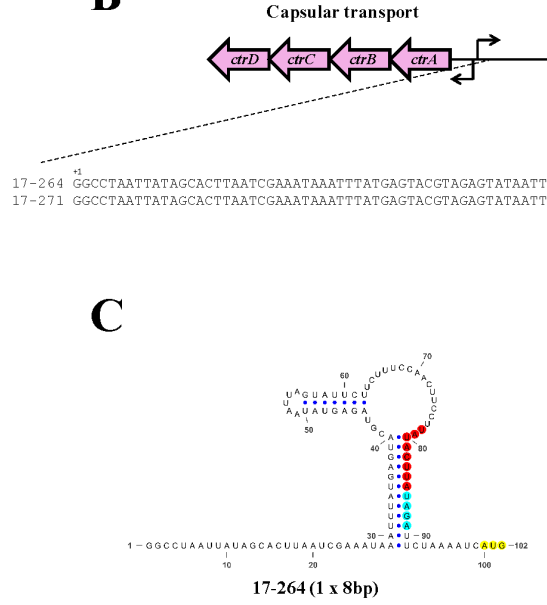

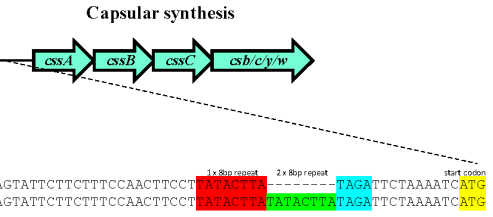

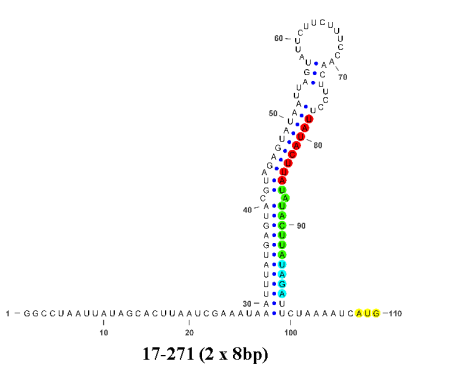

D

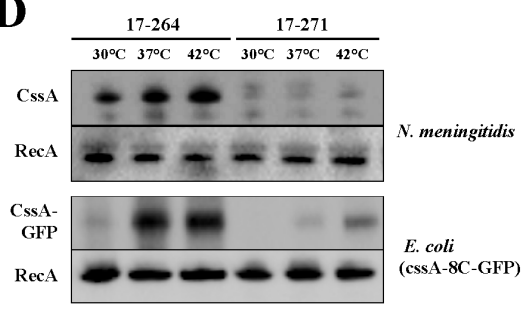

$\mathbf{E}$

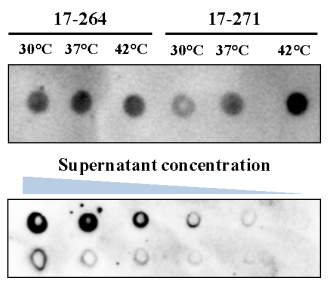

Fig. 1. 5'-UTR-cssA mapping, virulence factor characterisation, and temperature-mediated expression of CssA and capsule A) Immunoblot panel display the expression level of a variety of virulence related- and house-keeping proteins. Highlighted in bold are the virulence proteins upregulated in the invasive isolate 17-264; CssA, Opa and PilE. B) Illustration showing the ctr and cps loci with focus on the intergenic region. The 5'UTR-cssA sequences from the two clinical isolates were aligned. An 8bp deletion was observed in the invasive isolate.C) Secondary structure prediction of the 5'-UTR-cssA RNA using VARNA14 illustrating the thermodynamic stable stem-loop structure of the carrier isolate 17-271 ( $\Delta \mathrm{G}$ : $-15.60 \mathrm{kcal} / \mathrm{mol}$ ) and a smaller and less stable stem-loop of the invasive isolate 17-262 ( $\Delta \mathrm{G}:-11.30 \mathrm{kcal} / \mathrm{mol})$. The tandem repeat, RBS and start codon are marked in red/green, cyan and yellow, respectively. Small blue dots designate base pairing. D) Immunoblots of temperature mediated expression shows an increasing and constitutive high expression of CssA in the invasive isolate 17-264 compared to carrier isolate 17-271 (top). The 8bp tandem repeats function ectopically, controlling EGFP expression similar to their respective meningoccal background. (lower). E) Dot blots of capsular production on the surface of the bacteria show a constitutively high capsule production in the invasive isolate 17-264 compared to carrier isolate 17-271 (top). Serial dilution of supernatant from liquid culture grown at $37^{\circ} \mathrm{C}$ shows that the invasive isolate $17-264$ sheds more capsule into the medium compared to the carrier isolate 17-271 (lower). Data information: All blots are representative of at least three biological replicates.

growth temperature in the invasive isolate 17-264, while the carrier isolate 17-271 retain a temperature dependent production of capsule (Fig 1E - top). A fraction of the polysaccharide that are the constituents of the capsule are known to be released or "shed" into the surrounding environment by meningococci, when not recycled by the bacterium (15). The increased capsule expression in 17-264 is also evident when observing greater amount of shed capsule from liquid growth at $37^{\circ} \mathrm{C}$ compared to the 17-271 (Fig 1E - bottom).

To test if the hypercapsulation will improve bacterial survival when facing human immune factors, the two meningococcal isolates were subjected to serum killing assay using pooled serum from healthy individuals. Exposing bacteria to different serum concentrations revealed a trend of higher survival for the invasive isolate 17-264 compared to the carrier 17-271 after 20 minutes (Fig 2A - left). The difference becomes evident after 40 minutes of serum exposure, where the carrier isolate 17-271 was not able to resist 40 minutes serum exposure effectively in any higher serum concentration than $5 \%$, while the invasive isolate $17-264$ is able to survive in all serum concentrations, as well as growing more than the input colony forming unit (cfu) (Fig 2A - right). The hypercapsulation phenotype allows the bacteria to resist complement serum killing, however capsulation could inadvertently affect the ability of the bacteria to interact and adhere to pharyngeal cells due to inaccessible surface protein masked by the capsule (16). To investigate this, adhesion assays on human pharyngeal whether the hypercapsulation phenotype due to the loss of an $8 \mathrm{bp}$ repeat in the $5^{\prime}$-UTR-css $A$ is a common phenomenon and linked to cases of invasive infection. To address this, the $5^{\prime}$-UTR-css $A$ of meningococcal isolates reported as "invasive" or "carrier" in the PubMLST database from Europe during $1^{\text {st }}$ of January 2010 to $31^{\text {st }}$ of December 2018 was compiled and investigated. The geographical designation of Europe and time span were chosen due to the overall improved WGS and extensive cases reported in the PubMLST database, allowing a sufficient, large, and relevant dataset to be used for analysis. In addition, the two isolates in this study were associated with two European countries; Sweden and France. A total of 4325 invasive- and 176 carrier isolates fitting the search criteria were analysed. Sequences of their $5^{\prime}$-UTR-css $A$ were divided into the three known configurations; two times 8bp repeat (TATACTTATATACTTA), one 8bp (TATACTTA) and one 8bp with substitutionary mutations of either (TATGCTTA/TATGCCTA) that would revert capsule production back to the native two times $8 \mathrm{bp}$ repeat level. Our statistical analysis shows that the presence of the two times 8 bp repeat is similar for both groups with $75 \%(n=176)$ in carrier isolates and $73.2 \%(n=4325)$ for invasive isolates. Interestingly, the average occurrence of the single $8 \mathrm{bp}$ repeat (hypercapsulation) is only $5.1 \%$ in the carriers whereas the frequency is more than threefold higher at $16.3 \%$ in invasive isolates (Fig 3A). Inversely, the sequences with compensatory mutation revert to almost two fold higher frequency in carrier isolates at $19.9 \%$ compared to the invasive isolates at $10.5 \% . \chi^{2}$ - 
Karlsson et al., 20-03-2019 - preprint copy - BioRxiv
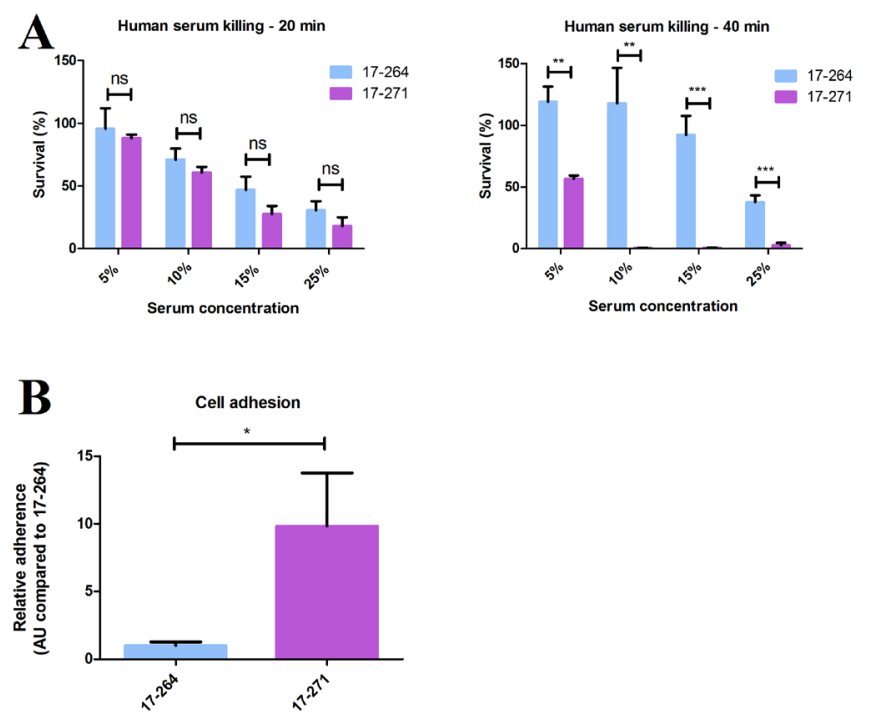

Fig. 2. Human serum killing- and cell adhesion assays. A) Human serum killing assay at various concentrations of serum (5-25\%) with 20 minutes of exposure (left) and 40 minutes of exposure (right). After 20 minutes, the invasive isolate 17-264 showed a higher survival trend compared to the carrier isolate 17-271. After 40 minutes exposure, 17264 was able to grow in the various serum concentrations whereas 17271 could only sustain the $5 \%$ serum. Statistical significance values are $5 \% ; p=0.0013,10 \% ; p=0.0037,15 \% ; p=0.0004,25 \% ; p=0.0008$. B) Cell adhesion assay using the human pharyngeal cell line Detroit-562. The graph was normalised to the adherence of the invasive isolate 17-264. The carrier isolate 17-271 is approximately 10 times better in adherence compared with the invasive isolate 17-264, $p=0.045$. Data information: All graphs are presented with mean \pm SEM. ${ }^{*} \mathrm{P} \leq 0.05$ (Student's t-test). Graphs and statistical analysis were generated using GraphPad Prism.

test was performed and the observed difference in frequency is statistically significant $(p=0.015)$.

The majority of the European invasive isolates investigated in this study are of serogroup B, with higher distribution of a single $8 \mathrm{bp}$ tandem repeat $(25.2 \%, \mathrm{n}=2343)$ than the other serogroups respectively, $\mathrm{C}$ $(12.3 \%, \mathrm{n}=277), \mathrm{Y}(5.5 \%, \mathrm{n}=642), \mathrm{W}(2.5 \%, \mathrm{n}=937)$ and in non groupable (NG) $(20.2 \%, n=94)$ (Fig 3B). As specific ccs are more prevalent in invasive disease, the configurations of $5^{\prime}$-UTR-css $A$ of invasive isolates were also divided into respective complexes (Fig 3C). The same cc ( $\operatorname{cc} 32)$ as the investigated clinical isolates used in this study showed an even higher frequency with the loss of an $8 \mathrm{bp}$ repeat, $27.8 \%(n=213)$, than the overall European invasive isolates of $16.3 \%$. To investigate whether the high frequency of the loss of an $8 \mathrm{bp}$ repeat among cc32 isolates is a recent occurrence, the $\operatorname{cc} 32$ data were also subdivided into years of incidence (2010-2018). The loss of an 8bp repeat frequency remains high throughout the years (Fig 3D).

\section{Discussion}

Our work supports a regulatory RNA to be directly involved in the clinical manifestation of meningococcal disease. Epidemiological analysis of 4501 meningococcal isolates reveal that the loss of an $8 \mathrm{bp}$ tandem repeat in this regulatory RNA is more than three times frequent in invasive clinical isolates thus emphasising its role in virulence. Molecular analyses from the two Swedish isolates in this study have further confirmed our previous finding that the $8 \mathrm{bp}$ tandem repeats in the 5'-UTR-css $A$ regulate CssA expression in a temperature dependent manner (11). In addition, we demonstrated that the higher expression of CssA leads to higher production of capsule as shown by the dot blot assays.

It is known from previous studies that both expression levels of T4P and capsule affects the ability of meningococci to adhere to human cells ( 17 , 18 ). Our results indicate that while the invasive isolate 17-264 express more PilE protein, the most abundant minor pilin in the makeup of the T4P it still has a reduced ability to adhere to cells. Our findings supports previous research that the thicker polysaccharide capsule could interfere with important surface structures such as T4P thus sequestering their function for adhesion to pharyngeal cells (19). Previous study has shown that T4P and Opa mediates endothelial interactions in a synergistic manner in capsulated strains (20). It is also known that expression of PilE and Opa is in unison to facilitate Neisserial microcolony formation (21).

Our analysis here also show nine copies of incomplete IS1655 elements in the carrier isolate, 17-271. All of the IS1655 hits were sequenced at the end of contigs in the WGS data and with a short alignment to the reported IS1655. This IS element is an exclusive feature of meningococcus and found in high numbers in several strains $(\underline{22}, \underline{23})$.

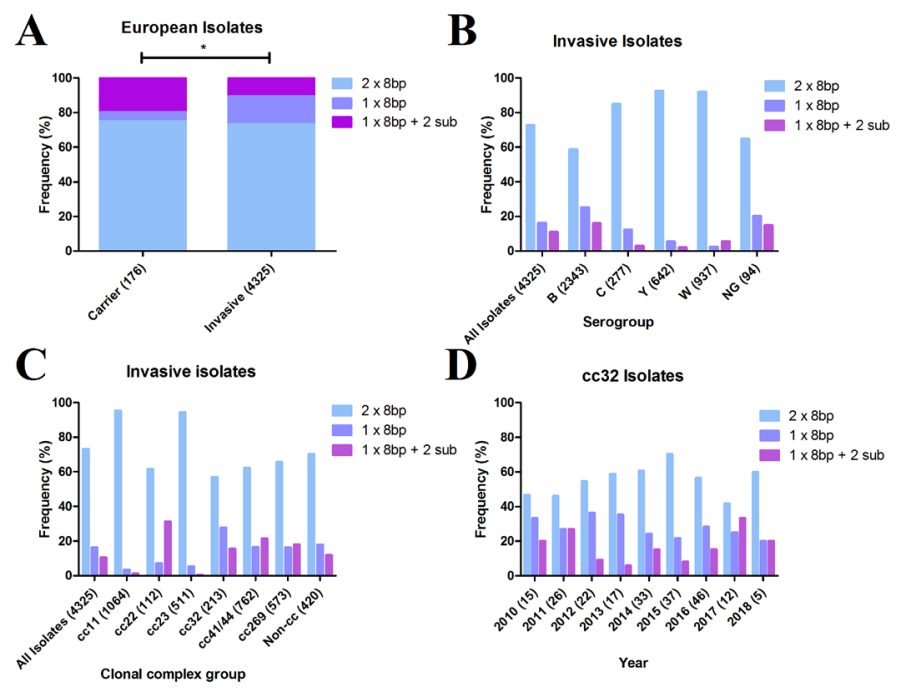

Fig. 3. Frequency distribution of $8 \mathrm{bp}$ tandem repeats among 4501 meningococcal isolates in Europe from 2010-2018. A) Frequency distribution showing a three times higher frequency of the $1 \times 8 \mathrm{bp}$ tandem repeat in the invasive isolates $(16.3 \%)$ compared to carrier isolates $(5.1 \%)$. The sequences with compensatory mutation revert to higher frequency for carrier isolates $(19.9 \%)$, and lower for invasive isolates $(10.5 \%) . \times 2$-test shows significant difference between the distributions (significance value of $p=0.015$ ). Post-hoc testing with Bonferroni correction revealed both the $1 \times 8 b p(p=0.00007)$ and $1 \times 8 b p+2 s u b$ $(p=0.0002)$ distributions to be significantly different between the carrier and invasive isolates. B) The distribution of $8 \mathrm{bp}$ tandem repeats among invasive isolates grouped into serogroups display the highest frequency of $1 \times 8 \mathrm{bp}$ tandem repeat in serogroup B (25.2\%) compared to other serogroups $(2.5-12.3 \%)$. C) Distribution of tandem repeats in different clonal complexes of invasive isolates shows that cc32 has the highest proportion (27.7\%) of $1 \times 8 \mathrm{bp}$ tandem repeat. D) Annual distribution of tandem repeats of cc32 reveals consistent frequencies throughout the years of 1 x 8bp repeat (range $20.0-36.4 \%$ ). Data information: Amount of isolates analysed are designated by $n$. ${ }^{*} P \leq 0.05$ ( $x 2$-test), ${ }^{*} P \leq 0.0083$ (Bonferroni corrected). All graphs and statistical analysis were generated using GraphPad Prism and SPSS. Numbers in brackets denotes number of isolates analysed. 
Karlsson et al., 20-03-2019 - preprint copy - BioRxiv

To date, no work has been done to investigate whether IS1655 is involved in meningococcal pathogenesis, given its prominent and diverse presence across the meningococcal genomes.

In our previous study investigating this $8 \mathrm{bp}$ tandem repeats (11), we speculated that the three configurations of the $8 \mathrm{bp}$ tandem repeats are an evolutionary step-by-step process. The native two $8 \mathrm{bp}$ tandem repeats and temperature regulated capsule expression are beneficial for the bacterium during non-invasive colonisation of the host nasopharynx. Meningococci face environment switches constantly, such as localised inflammation caused by the bacterium itself, other microbes, or by entering the blood circulation. It is our hypothesis that the stress induced by high amounts of immune factors together with a febrile condition will make the thermostable two 8 bp repeats superfluous, as the need for protection by expressing more polysaccharide capsules is great. This selection pressure induced by the host alters the meningococcal population through the loss of an $8 \mathrm{bp}$ repeat in the $5^{\prime}$ UTR-css $A$ to produce more capsule constitutively. The rapid onset of the invasive disease together with the presence of all three different $5^{\prime}$ UTR-css $A$ thermosensors in carrier isolates suggest this selection to take place in the nasopharynx. To investigate the loss of $8 \mathrm{bp}$ mechanism, we subjected the carrier isolate 17-271 to a sub-lethal concentration of $6 \%$ human serum stress. After two and a half hours, we were able to identify colonies that have lost a single 8bp (Fig S3). Stress induced modification of tandem repeats have previously been shown to regulate other immune evasion factors such as the meningococcal PorA outer membrane protein (24) and the gonococcal iron-repressible protein FetA (25). These tandem repeats are prone to strand-slipping during DNA replication especially during stress condition as a form of bacterial selection strategy to the new environment (26). During recovery conditions after stress, the meningococci would shift towards a population that restores colonisation by reducing capsule expression with a reinstated thermostable 5 '-UTR-css $A$ by one or two point mutations to strengthen the stem-loop structure (Fig S4). Interestingly, among the 4501 meningococcal isolates, we could observe this phenomenon as an almost two-fold higher frequency of one $8 \mathrm{bp}$ tandem repeat with substitutionary mutations among the carrier isolates compared to the invasive isolates. Capsular switching is a phenomenon where meningococci acquire parts of the cps locus from other serogroups such as B to C or the reverse (27). The serogroup C, cc-32 isolates used in this study could support a capsule switching event prior to the alteration of the $5^{\prime}$-UTR-css $A$ as similar capsular switching has been reported previously $(\underline{28}, \underline{29})$. It is interesting to hypothesise how capsular switching could also contribute to the "reversal" of a $1 \mathrm{x} 8 \mathrm{bp}$ or $1 \times 8 b p+2$ sub 5 '-UTR-css $A$ to a "native" 2 x8bp 5'-UTR-css $A$ as a consequence of capsular switching bringing the 5 '-UTR-css $A$ of the "donor" DNA, however previous work has shown the intergenic region between $\operatorname{ctr} A$ and $\operatorname{css} A$ is not included in capsular switching (27).

While it is difficult to determine all the host genetic- and environment factors involved, we postulate that the loss of an $8 \mathrm{bp}$ tandem repeat hypercapsulation phenotype of the 17-264 isolate contributed to the fatal disease manifestation in the adolescent girl from Sweden. Statistical analysis further strengthen this hypothesis as the one $8 \mathrm{bp}$ tandem repeat is three-fold more frequent among invasive isolates compared to the carrier isolates. Our epidemiology data also show the prevalence of the loss of an $8 \mathrm{bp}$ tandem repeat is most prominent in Serogroup B, cc32. In addition we demonstrated that invasive isolates of other cc such as cc41/44 regulate CssA expression solely depending on the configuration of the $8 \mathrm{bp}$ tandem repeats (Fig S5) regardless of cc. It is important to note that the isolation of clinical isolates are from two distinct sites; the nasopharynx (carrier) and blood/cerebrospinal fluid (CSF) (invasive). The presence of all three configurations of the $8 \mathrm{bp}$ tandem repeats in both sites reflect the importance of this regulatory RNA in controlling its capsular biosynthesis in both environments. However, the significant higher prevalence of the hypercapsulated single $8 \mathrm{bp}$ configuration observed among the invasive isolates found in blood/CSF would be beneficial for the bacteria to evade the host immune killing. It is hard not speculate that while the single $8 \mathrm{bp}$ background could be due to isolation sites, our statistics finding emphasize that this regulatory RNA plays a pivotal role in virulence and is associated meningococcal disease manifestation.

Due to the lack of suitable infection models, we believe that molecular comparative WGS between meningococcal isolates from invasive and carrier cases is the best alternative. With WGS, polymorphism comparisons should include regions such as 5'-UTRs and regulatory RNAs as they are significantly involved in the expression of many virulence factors exemplified here by capsule production. Comparative WGS will facilitate future studies into underlying mechanisms involved in disease manifestation, improve diagnostic techniques and treatments by clinicians and advance future vaccine development.

\section{Materialsand Methods}

\section{Bacterial isolates and DNA extraction.}

The bacteria are cultured overnight on chocolate agar in $37^{\circ} \mathrm{C}$ and $5 \%$ $\mathrm{CO}_{2}$, serogrouped by coagglutination, and stored at $-70^{\circ} \mathrm{C}$. In this study, both meningococcal isolates were isolated during May 2017 and whole-genome sequencing (WGS) was performed. DNA was extracted using a customized protocol and QIAsymphony DSP virus/pathogen Midi kit on the QIAsymphony system (Qiagen, Hilden, Germany). WGS was performed using the Nextera XT DNA library preparation kit, the MiSeq reagent kit v3, 600 cycles on the Illumina MiSeq platform (Illumina, San Diego, CA). The reads were assembled de novo using Velvet (30). The quality of sequencing was controlled by the N50 value, contig count and coverage. The sequences were trimmed until the average base quality (Phred score) was $>30$ in a window of 20 bases. The assemblies were uploaded to the Neisseria PubMLST database, and the sequences were automatically scanned and tagged against defined "NEIS" loci in the database (31). Information regarding the typing of the French isolate was obtained through personal communication with Dr. Muhamed-Kheir Taha, Institut Pasteur, Paris

\section{Bacterial culturing}

For all other purposes, bacteria were grown with Brain Heart Infusion (BHI) broth (Sigma-Aldrich, Saint-Louis, MO) or agar supplemented with horse serum (Thermo Fisher Scientific, Waltham, MA). For all experiments, bacteria were inoculated on $\mathrm{BHI}$ agar for $16 \mathrm{~h}$, in $37^{\circ} \mathrm{C}$ and $5 \% \mathrm{CO}_{2}$. Liquid cultures were grown in BHI broth starting at an optical density at $600 \mathrm{~nm}\left(\mathrm{OD}_{600}\right)$ of $0 \cdot 05$ and cultured to $\mathrm{OD}_{600}: 0 \cdot 6$ where protein or DNA were harvested.

\section{Scanning Electron Microscopy}

Bacteria were fixed with $6 \%$ paraformaldehyde and transferred to a presputtered filter (Polyamide, NL 16, GE Healthcare UK Limited, Buckinghamshire, UK), rinsed in distilled water and placed in $70 \%$ ethanol for 10 minutes, $95 \%$ ethanol for 10 minutes and absolute ethanol for 15 minutes, all at $4{ }^{\circ} \mathrm{C}$ and then into acetone. Specimens were then dried using a critical point dryer (Balzer, CPD 010, Lichtenstein) with $\mathrm{CO}_{2}$. After drying, filter was mounted on an aluminium stub and coated with Platinum (Q150T ES, West Sussex, 
bioRxiv preprint doi: https://doi.org/10.1101/583476; this version posted March 20, 2019. The copyright holder for this preprint (which was not certified by peer review) is the author/funder, who has granted bioRxiv a license to display the preprint in perpetuity. It is made available under aCC-BY 4.0 International license.

Karlsson et al., 20-03-2019 - preprint copy - BioRxiv

UK). The specimens were analysed in an Ultra 55 field emission scanning electron microscope (Zeiss, Oberkochen, Germany) at $5 \mathrm{kV}$.

\section{Immunoblotting and dot blotting}

For immunoblotting, bacterial pellet was spun down at 7,000 $\mathrm{g}$ for 10 minutes and lysed in Buffer A $(200 \mathrm{mM} \mathrm{KCl}, 50 \mathrm{mM}$ Tris- $\mathrm{HCl} \mathrm{pH} 8 \cdot 0$, $1 \mathrm{mM}$ EDTA, $10 \%$ Glycerol). Cell debris was spun down at 12,000 $\mathrm{g}$ for 5 minutes and lysate collected for protein quantification. using BCA (Thermo Fisher Scientific). SDS-loading buffer was added and boiled at $98^{\circ} \mathrm{C}$ for 10 minutes before protein was subjected to electrophoresis on $4-12 \%$ Bis-Tris gel (Thermo Fisher Sceintific) and run at $110 \mathrm{~V}$. Gels were transferred to PVDF membranes using the Trans-Blot Turbo system (Bio-Rad, Hercules, CA). For dot blots, bacteria were harvested from plates grown at $30-, 37-$, and $42^{\circ} \mathrm{C}$, and supernatant was harvested from liquid growth at $37^{\circ} \mathrm{C}$. Supernatant was sterile filtered and serial diluted in PBS while harvested bacteria were lysed as described previously and diluted $1 \times 10^{-4}$ in PBS. Amersham Hybond-P PVDF membranes (GE healthcare, Chicago, IL) were activated and $10 \mu 1$ of the samples were dotted onto the membrane and left to dry for one hour at $37^{\circ} \mathrm{C}$. Membranes were blocked in $5 \%$ milk for one hour at room temperature (RT) and incubated with primary antibody/anti-sera in PBS $+0 \cdot 1 \%$ Tween, for one hour at RT. After washing membrane four times 5 minutes, secondary antibody was added in PBS $+0 \cdot 1 \%$ Tween for one hour RT. Membranes were exposed by Amersham ECL reagents (GE healthcare) and visualised by GelDoc XRS+ (Bio-Rad). Commercial antibodies used was anti-RecA, (Abcam, ab63797) (crossreacts with $N$. meningitidis RecA), anti-PorA P1.7, (NIBSC, 01/514) and anti-fHbp, (NIBSC, 13/216). The remaining antibodies used are custom antibodies obtained from Yvonne Pannekoek (antiHfq), Hank Seifert (anti-PilQ), Ann-Beth Jonsson (anti-PilC) and Ryoma Nakao (anti-Rmpm, -PilE, -Opa, -CssA and GroEL).

\section{Human serum stress and killing assay}

Human serum killing assay was performed with bacteria resuspended in PBS and diluted to a concentration of $1 \times 10^{5} \mathrm{CFU} / \mathrm{ml}$ in DMEMmedium (Gibco, Thermo Fisher Scientific). Serum from healthy humans (Sigma-Aldrich) was used to stress bacteria at $37^{\circ} \mathrm{C}$ in the presence of $5 \% \mathrm{CO} 2$ for $20-$, or 40 minutes (killing assay) or hours (serum stress induction). Survival of bacteria in the presence of sera was determined by dot-plating $10 \mu 1$ and counting CFUs after overnight incubation. The percentage of survival was measured relative to input.

\section{Bacterial adhesion assay}

Detroit 562 cells were cultured in DMEM, supplemented with $10 \%$ FBS (GE Healthcare). $5 \times 10^{5}$ cells were seeded per bacterial isolate tested. Cells were washed with PBS and covered with $2 \mathrm{~mL}$ DMEM without FBS. Bacteria were resuspended in PBS to an $\mathrm{OD}_{600}: 0.5$ and added to the cells at a MOI of 50 . Bacteria and cells were incubated at $37^{\circ} \mathrm{C}$ at $5 \% \mathrm{CO}_{2}$ for one hour, and washed three times with PBS. Cells were lysed for 10 min with $1 \%$ saponin (Sigma-Aldrich), and the lysate was diluted 1:3 in PBS before dribble-plating and incubated at $37^{\circ} \mathrm{C}$, ON and analysed the next day. CFU of the negative control (no cells) were subtracted from CFU of the output. The result was normalised to the CFU of the input.

\section{Whole-genome sequencing with loci comparison}

17-264 and 17-271 isolates were compared using the "Genome comparator" function in the PubMLST database. Sequence alignments were performed for all loci that were marked as different between the isolates. For further protein sequence prediction and alignment, online tools; ExPASy and Clustal Omega (SIB Swiss Institute of Bioinformatics, Lausanne, Switzerland) were used.

\section{5 '-UTR-css A mapping and in silico RNA structure predictions}

The PubMLST database was used for identifying meningococcal isolates and selected according to the following search criteria. The range from the $1^{\text {st }}$ of January 2010 to $31^{\text {st }}$ of December 2018 and geographic restriction to the continent of Europe. The searches were then separated by the designation of "carrier" or "invasive (unspecified/other)". Hits were BLAST to a $200 \mathrm{bp}$ long sequence that encompasses the 5'UTR of the $\operatorname{css} A$ gene and the beginning of the coding region of $\operatorname{css} A$. The results were exported and analysed by excluding all hits that had less than 100bp alignment to the search query. Any isolate that was suspect of non-canonical 5'UTR-css $A$ or where the sequence could not be retrieved, was excluded from the analysis. To predict, analyse, and visualise secondary structure of RNA, multiple available softwares were used. RNAfold by ViennaRNA package (32) and mFold ( 33 ) were used for structure prediction data and folding based on the minimum free energy. VARNA (34) was used to visualise the secondary structure obtained together with annotated nucleotides.

\section{Statistical methods}

All experiments were performed with two or three biological replicates. Data from human serum killing assay and bacterial adhesion assay are shown with mean \pm SEM, and students t-test was used to calculate statistical significance. Normal distribution are assumed for this data. The observational data of the 5'UTR-css $A$ mapping is shown with mean distribution and $\chi^{2}$-test was performed to calculate statistical significance in group distributions. $\mathrm{P}$ values of less than 0.05 was considered statistically significant. Graphpad Prism v5.04 (Graphpad software, Inc, La Jolla, CA) and SPSS v25 (IBM, Armonk, NY) was used to plot data and perform statistical analysis.

\section{End Matter}

\section{Author Contributions and Notes}

S.J. performed the meningococcal isolates isolation, typing and WGS J.K., H.E. and E.L. performed the experiments and analysed the data. J.K. performed the European clinical data collection and analysis. E.L. provided overall direction. E.L and J.K. performed literature search and wrote the manuscript with input from H.E. and S.J.

The authors declare no conflict of interest.

This article contains supporting information online.

\section{Acknowledgments}

We thank Dr Francesco Righetti and Dr Kristiina Tammimies for critical reading of the manuscript. Most of the non-commercially available antibodies used were gifts from Dr Ryoma Nakao from The National Institute of Infectious Diseases at Tokyo, Japan. This publication made use of the Neisseria Multi Locus Sequence Typing website (https://pubmlst.org/neisseria/) developed by Keith Jolley and sited at the University of Oxford (ㅌ5). The development of this site has been funded by the Wellcome Trust and European Union. This study also made use of the Meningitis Research Foundation Meningococcus Genome Library (http://www.meningitis.org/research/genome) developed by Public Health England, the Wellcome Trust Sanger Institute and the University of Oxford as a collaboration, a project funded by Meningitis Research Foundation. This work was funded by the Swedish Foundation for Strategic Research (ICA14-0013), Knut and 
bioRxiv preprint doi: https://doi.org/10.1101/583476; this version posted March 20, 2019. The copyright holder for this preprint (which was not certified by peer review) is the author/funder, who has granted bioRxiv a license to display the preprint in perpetuity. It is made available under aCC-BY 4.0 International license.

Karlsson et al., 20-03-2019 - preprint copy - BioRxiv

Alice Wallenberg Foundation, and Swedish Research Council (Dnr: 2014-2050).

\section{References}

1. Christensen H, May M, Bowen L, Hickman M, Trotter CL. 2010. Meningococcal carriage by age: a systematic review and metaanalysis. Lancet Infect Dis 10:853-61.

2. Harrison LH, Pelton SI, Wilder-Smith A, Holst J, Safadi MA, Vazquez JA, Taha MK, LaForce FM, von Gottberg A, Borrow R, Plotkin SA. 2011. The Global Meningococcal Initiative: recommendations for reducing the global burden of meningococcal disease. Vaccine 29:3363-71.

3. Goldschneider I, Gotschlich EC, Artenstein MS. 1969. Human immunity to the meningococcus. I. The role of humoral antibodies. J Exp Med 129:1307-26.

4. Simmons RD, Kirwan P, Beebeejaun K, Riordan A, Borrow R, Ramsay ME, Delpech V, Lattimore S, Ladhani S. 2015. Risk of invasive meningococcal disease in children and adults with HIV in England: a population-based cohort study. BMC Med 13:297.

5. Whittaker R, Dias JG, Ramliden M, Kodmon C, Economopoulou A, Beer N, Pastore Celentano L, disease Enmfim. 2017. The epidemiology of invasive meningococcal disease in EU/EEA countries, 2004-2014. Vaccine 35:2034-2041.

6. Harrison OB, Claus H, Jiang Y, Bennett JS, Bratcher HB, Jolley KA, Corton C, Care R, Poolman JT, Zollinger WD, Frasch CE, Stephens DS, Feavers I, Frosch M, Parkhill J, Vogel U, Quail MA, Bentley SD, Maiden MC. 2013. Description and nomenclature of Neisseria meningitidis capsule locus. Emerg Infect Dis 19:566-73.

7. Maiden MC, Bygraves JA, Feil E, Morelli G, Russell JE, Urwin R, Zhang Q, Zhou J, Zurth K, Caugant DA, Feavers IM, Achtman M, Spratt BG. 1998. Multilocus sequence typing: a portable approach to the identification of clones within populations of pathogenic microorganisms. Proc Natl Acad Sci U S A 95:3140-5.

8. Helm RA, Seifert HS. 2010. Frequency and rate of pilin antigenic variation of Neisseria meningitidis. J Bacteriol 192:3822-3.

9. Power PM, Roddam LF, Rutter K, Fitzpatrick SZ, Srikhanta YN, Jennings MP. 2003. Genetic characterization of pilin glycosylation and phase variation in Neisseria meningitidis. Mol Microbiol 49:83347.

10. Srikhanta $\mathrm{YN}$, Dowideit SJ, Edwards JL, Falsetta $\mathrm{ML}, \mathrm{Wu} \mathrm{HJ}$, Harrison OB, Fox KL, Seib KL, Maguire TL, Wang AH, Maiden MC, Grimmond SM, Apicella MA, Jennings MP. 2009. Phasevarions mediate random switching of gene expression in pathogenic Neisseria. PLoS Pathog 5:e1000400.

11. Loh E, Kugelberg E, Tracy A, Zhang Q, Gollan B, Ewles H, Chalmers R, Pelicic V, Tang CM. 2013. Temperature triggers immune evasion by Neisseria meningitidis. Nature 502:237-40.

12. Tzeng YL, Noble C, Stephens DS. 2003. Genetic basis for biosynthesis of the (alpha 1-->4)-linked $\mathrm{N}$-acetyl-D-glucosamine 1phosphate capsule of Neisseria meningitidis serogroup X. Infect Immun 71:6712-20.

13. Deghmane AE, Petit S, Topilko A, Pereira $Y$, Giorgini D, Larribe $M$, Taha MK. 2000. Intimate adhesion of Neisseria meningitidis to human epithelial cells is under the control of the crgA gene, a novel LysR-type transcriptional regulator. EMBO J 19:1068-78.

14. Bos MP, Tommassen J. 2005. Viability of a capsule- and lipopolysaccharide-deficient mutant of Neisseria meningitidis. Infect Immun 73:6194-7.

15. Woodhams KL, Chan JM, Lenz JD, Hackett KT, Dillard JP. 2013. Peptidoglycan fragment release from Neisseria meningitidis. Infect Immun 81:3490-8.

16. Hill DJ, Griffiths NJ, Borodina E, Virji M. 2010. Cellular and molecular biology of Neisseria meningitidis colonization and invasive disease. Clin Sci (Lond) 118:547-64.
17. Virji M, Makepeace K, Peak IRA, Ferguson DJP, Jennings MP, Moxon ER. 1995. Opc- and pilus-dependent interactions of meningococci with human endothelial cells: molecular mechanisms and modulation by surface polysaccharides. Mol Microbiol 18:741754.

18. Bartley SN, Tzeng YL, Heel K, Lee CW, Mowlaboccus S, Seemann T, Lu W, Lin YH, Ryan CS, Peacock C, Stephens DS, Davies JK, Kahler CM. 2013. Attachment and invasion of Neisseria meningitidis to host cells is related to surface hydrophobicity, bacterial cell size and capsule. PLoS One 8:e55798.

19. Stephens DS, Spellman PA, Swartley JS. 1993. Effect of the (alpha 2-->8)-linked polysialic acid capsule on adherence of Neisseria meningitidis to human mucosal cells. J Infect Dis 167:475-9.

20. Rowe HA, Griffiths NJ, Hill DJ, Virji M. 2007. Co-ordinate action of bacterial adhesins and human carcinoembryonic antigen receptors in enhanced cellular invasion by capsulate serum resistant Neisseria meningitidis. Cell Microbiol 9:154-68.

21. Griffiss JM, Lammel CJ, Wang J, Dekker NP, Brooks GF. 1999. Neisseria gonorrhoeae coordinately uses Pili and Opa to activate HEC-1-B cell microvilli, which causes engulfment of the gonococci. Infect Immun 67:3469-80.

22. Kiss J, Nagy Z, Toth G, Kiss GB, Jakab J, Chandler M, Olasz F. 2007. Transposition and target specificity of the typical IS 30 family element IS1655 from Neisseria meningitidis. Mol Microbiol 63:173147.

23. Schoen C, Blom J, Claus $H$, Schramm-Gluck A, Brandt $P$, Muller $T$, Goesmann A, Joseph B, Konietzny S, Kurzai O, Schmitt C, Friedrich T, Linke B, Vogel U, Frosch M. 2008. Whole-genome comparison of disease and carriage strains provides insights into virulence evolution in Neisseria meningitidis. Proc Natl Acad Sci U S A 105:3473-8

24. van der Ende A, Hopman CT, Dankert J. 2000. Multiple mechanisms of phase variation of PorA in Neisseria meningitidis. Infect Immun 68:6685-90.

25. Carson SD, Stone B, Beucher M, Fu J, Sparling PF. 2000. Phase variation of the gonococcal siderophore receptor FetA. Mol Microbiol 36:585-93.

26. Zhou K, Aertsen A, Michiels CW. 2014. The role of variable DNA tandem repeats in bacterial adaptation. FEMS Microbiol Rev 38:11941.

27. Swartley JS, Marfin AA, Edupuganti S, Liu LJ, Cieslak P, Perkins B, Wenger JD, Stephens DS. 1997. Capsule switching of Neisseria meningitidis. Proc Natl Acad Sci U S A 94:271-6.

28. Harrison LH, Shutt KA, Schmink SE, Marsh JW, Harcourt BH, Wang $X$, Whitney AM, Stephens DS, Cohn AA, Messonnier NE, Mayer LW. 2010. Population structure and capsular switching of invasive Neisseria meningitidis isolates in the pre-meningococcal conjugate vaccine era--United States, 2000-2005. J Infect Dis 201:1208-24.

29. Wang X, Shutt KA, Vuong JT, Cohn A, MacNeil J, Schmink S, Plikaytis B, Messonnier NE, Harrison LH, Clark TA, Mayer LW. 2015. Changes in the Population Structure of Invasive Neisseria meningitidis in the United States After Quadrivalent Meningococcal Conjugate Vaccine Licensure. J Infect Dis 211:1887-94.

30. Zerbino DR. 2010. Using the Velvet de novo assembler for shortread sequencing technologies. Curr Protoc Bioinformatics Chapter 11:Unit 115.

31. Bratcher HB, Corton C, Jolley KA, Parkhill J, Maiden MC. 2014. A gene-by-gene population genomics platform: de novo assembly, annotation and genealogical analysis of 108 representative Neisseria meningitidis genomes. BMC Genomics 15:1138.

32. Lorenz R, Bernhart SH, Honer Zu Siederdissen C, Tafer H, Flamm C, Stadler PF, Hofacker IL. 2011. ViennaRNA Package 2.0. Algorithms Mol Biol 6:26.

33. Zuker M. 2003. Mfold web server for nucleic acid folding and hybridization prediction. Nucleic Acids Res 31:3406-15. 
bioRxiv preprint doi: https://doi org/10.1101/583476; this version posted March 20, 2019. The copyright holder for this preprint (which was not certified by peer review) is the author/funder, who has granted bioRxiv a license to display the preprint in perpetuity. It is made available under aCC-BY 4.0 International license.

Karlsson et al., 20-03-2019 - preprint copy - BioRxiv

34. Darty K, Denise A, Ponty Y. 2009. VARNA: Interactive drawing and editing of the RNA secondary structure. Bioinformatics 25:1974-5.

35. Jolley KA, Maiden MC. 2010. BIGSdb: Scalable analysis of bacterial genome variation at the population level. BMC Bioinformatics 11:595. 